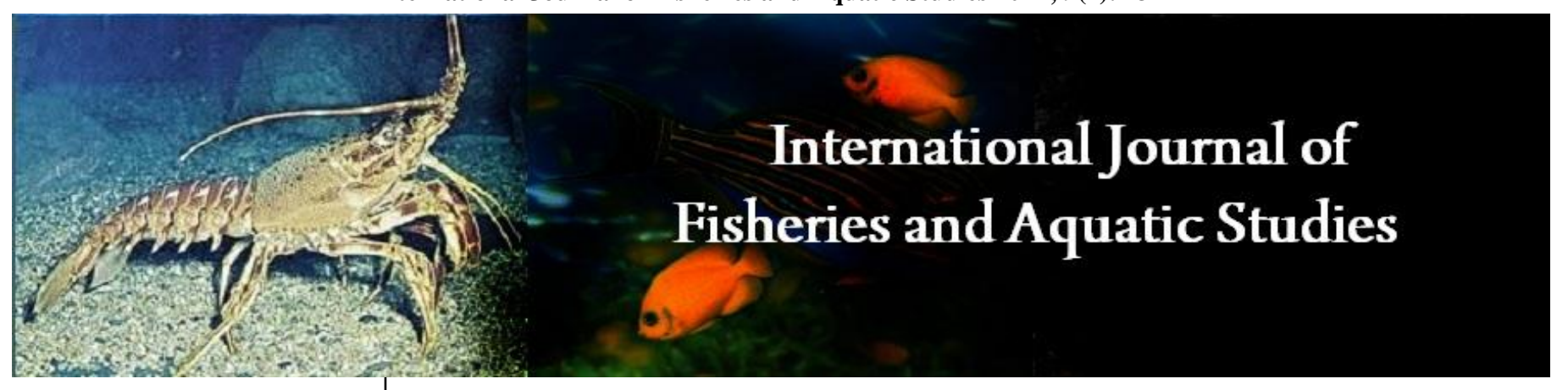

E-ISSN: 2347-5129

P-ISSN: 2394-0506

(ICV-Poland) Impact Value: 5.62

(GIF) Impact Factor: 0.549

IJFAS 2021; 9(1): 23-27

(C) 2021 IJFAS

www.fisheriesjournal.com

Received: 03-11-2020

Accepted: 11-12-2020

\section{Z Ferdoushi}

Professor, Department of

Fisheries Management, Faculty

of Fisheries, Hajee Mohammad

Danesh Science and Technology

University, Dinajpur,

Bangladesh

\section{MH Rasid}

Department of Fisheries

Management, Faculty of

Fisheries, Hajee Mohammad

Danesh Science and Technology

University, Bangladesh

\section{ZP Patwary}

Department of Aquaculture

Faculty of Fisheries

Hajee Mohammad Danesh

Science and Technology

University, Bangladesh

\section{TH Sarkar}

Department of Fisheries

Management, Faculty of

Fisheries, Hajee Mohammad

Danesh Science and Technology

University, Bangladesh

MI Akter

Faculty of Fisheries

Hajee Mohammad Danesh

Science and Technology

University, Bangladesh

\section{Corresponding Author:}

\section{Z Ferdoushi}

Professor, Department of

Fisheries Management, Faculty of Fisheries, Hajee Mohammad Danesh Science and Technology University, Dinajpur,

Bangladesh

\section{Monitoring and assessing the physico-chemical water properties and planktonic communities in tilapia nursing pond}

\author{
Z Ferdoushi, MH Rasid, ZP Patwary, TH Sarkar and MI Akter
}

DOI: https://doi.org/10.22271/fish.2021.v9.i1a.2383

\begin{abstract}
Water samples were collected from three different size categories of tilapia nursing ponds for a period of 2 months from November to December, 2016. Among different water quality parameters only water level and temperature varied significantly. However all the water quality parameters were found to remain within suitable ranges for tilapia fry rearing. The study revealed a total of 61 genus of plankton. Among them 49 phytoplankton genus were identified with 26 belongs to Chlorophyceae, 12 to Bacillariophyceae, 9 to Cyanophyceae and 2 to Euglenophyceae. Whereas, 12 genera of zooplankton consisting 6 genera of Rotifera, 3 to Copepoda, 2 to Cladocera and 1 to crustacean larvae. However, the planktonic communities were also pond did not vary significantly throughout the study period. Total phytoplankton covered more that $70 \%$ of the planktonic community. Chlorophyceae comprised more than $44 \%$ in all ponds followed by bacillariophycease, cyanophycease and euglenophyceae. On the other hand, Rotifera was dominant group among the zooplankton and varied significantly with the size and time. It can be concluded that the water quality parameters and planktonic abundance of nursery ponds found within optimum and suitable ranges.
\end{abstract}

Keywords: Nursery pond, tilapia, water quality, phytoplankton, zooplankton

\section{Introduction}

Tilapia (Oreochromis mossambicus), which is considered one of most important cultured species to meet the increased protein demand in the world. It is popularly known as aquatic chicken and become the third most important fish in aquaculture after carps and salmonids with production (Fessehaye, 2006) ${ }^{[10]}$. The world aquaculture production of tilapia is 4.0 million tonnes with an estimated value of around $\$ 3$ billion. FAO (2015) ${ }^{[9]}$ reports indicate that the global tilapia production is expected to reach 7.3 million tons by 2030 . To meet the enormous demand for protein source majority of the people depends largely on fishes which is cheap in comparison to other protein sources in Bangladesh. After 1999, there was a tremendous progress in tilapia farming in Bangladesh. During 2012-2013 fiscal year, the tilapia production was 2,28,450 $\mathrm{MT}$ (DoF 2014) ${ }^{[8]}$, which increased to 3,77,346 MT contributing 9.73\% of total production in Bangladesh during 2015-2016 (FRSS 2017) ${ }^{[11]}$.

However, the demand of tilapia is increasing in international market day by day which eventually encourages the business and research for more tilapia production. If modern farming methods and technology can be used, then it would generate more income. Though, farmers are facing different problems in farming both in fry and table fish production, like water quality deterioration, poisoning, diseases through using drugs feed etc. While, the purpose of fish farming is to enable farmers to attain maximum fish growth and production for profit maximization. The physico-chemical and biological attributes of a water body are principle determinants of fish growth rates and development (Jhingran, 1991) ${ }^{[14]}$. Moreover, the activity depends entirely on water for fish feeding, growth and performance of other biological functions. Therefore, it is no surprise that the success of fish farming depends greatly on the water quality management schemes as well as good understanding of water quality. Physical and chemical characteristics such as temperature, transparency, dissolved oxygen, $\mathrm{pH}$, Chlorophyll-a, nutrients and the potential danger of toxic elements must be considered for successful fish farming (Johnson, 1995) ${ }^{[15]}$. 
In addition, analysis of the plankton community in fish farm systems is an important tool to evaluate water quality conditions, as changes in nutrient concentrations determine changes in species composition. So, determining or assessing water quality parameters play a significant role in the biology and physiology of fish including tilapia, which should be kept within range for their good performance (Boyd and Tucker, 1998) ${ }^{[7]}$.

However, tilapia farmers in Bangladesh have little information about the dynamics of different water quality parameters. Researchers till now mostly concerned on the food, feeding rate, growth rate and economics of tilapia farming (Gupta et al. 2012) ${ }^{[8]}$. Therefore, a number of research works on water quality i.e. physico-chemical parameters of water body, and ecological, limnological and biological aspects of pond is very much needed in Bangladesh for better management practices. Considering its importance the present research was designed as a case study to assess the physico-chemical water quality parameters as well as the planktonic community in tilapia nursing ponds.

\section{Materials and Methods \\ Study area and Sampling}

Three different size categories of nursery ponds were selected and considered as treatments for research purpose. Each treatment with triplicates was set for sample collection. Treatment 1 had three ponds having an area of 20 decimal considered as small size category pond, medium size category 25 decimal (Treatment 2) and rest three ponds each was 30 decimal in size were considered as Treatment 3 or large category. Samplings were conducted from November to December 2016 during the nursing time of tilapia fish. Water temperature $\left({ }^{\circ} \mathrm{C}\right)$, transparency $(\mathrm{cm})$, water level $(\mathrm{m}), \mathrm{pH}$, dissolved oxygen $(\mathrm{mg} / \mathrm{L})$ were recorded in the pond sites. Total alkalinity $(\mathrm{mg} / \mathrm{L})$, chlorophyll-a $(\mu \mathrm{g} / \mathrm{L})$ and plankton analysis were also determined in the laboratory of the Department of Fisheries Management, Faculty of Fisheries, HSTU, Dinajpur.

\section{Plankton Analysis}

Plankton samples were collected by filtration technique. Ten liters of water samples was collected in a plastic bucket and filtered through plankton net of $25 \mu \mathrm{m}$ mesh size. Then concentrated sample preserved in $4 \%$ formalin solution. Taxonomic identification up to genus level of plankton was carried out with the help of taxonomic keys from the text book of Barbar and Haworth (1981) ${ }^{[4]}$, Bellinger (1992) ${ }^{[5]}$, Pontin (1978) ${ }^{[21]}$, Lind and Brook (1980) ${ }^{[18]}$ under the binocular microscope.

Then plankton abundance i.e. both phytoplankton and zooplankton were estimated or calculated by applying the following formula Rahman (1992) ${ }^{[22]}$.

$$
\text { Number of plankton }(\mathrm{N})=\frac{\mathrm{A} \times \mathrm{C} \times 1000}{\mathrm{~F} \times \mathrm{V} \times \mathrm{L}}
$$

Where

$\mathrm{N}=$ No. of plankton cells or units per liter original water sample

$\mathrm{A}=$ Total no. of plankton counted

$\mathrm{C}=$ Volume of final concentration of samples in $\mathrm{ml}$

$\mathrm{V}=$ Volume of a field i.e. 1 cu.mm

$\mathrm{F}=$ Number of fields counted

$\mathrm{L}=$ Volume of original water sample in liter
Statistical Analysis: Two-way Analysis of Variance (ANOVA) is a statistical technique used to determine whether there are any differences in mean between groups or treatments. All statistical analyses were carried out using SPSS (Statistical Package for Social science) version 20.0.

\section{Results and Discussion}

The mean values of different physico-chemical water quality parameters in tilapia nursery ponds are presented in Table I. Among different physical parameters, the temperature and water level found to vary with the time and with size. The mean values of water temperature in three size categories were observed as $23.72^{\circ} \mathrm{C}, 23.84^{\circ} \mathrm{C}$ and $23.99^{\circ} \mathrm{C}$ respectively (Table 1). Jhingran (1991) ${ }^{[15]}$ noted that for phytoplankton production the suitable range of temperature ranged between 18.3 to $37.9^{\circ} \mathrm{C}$. Kunlasak et al. (2013) ${ }^{[17]}$ also measured the water temperature in tilapia ponds ranged from $29.4^{\circ} \mathrm{C}$ to $31.8^{\circ} \mathrm{C}$. Similar observation was also recorded in the present study which was found to remain within the suitable range.

In addition, Boyd (1982) ${ }^{[6]}$. Suggested that the transparency between $15 \mathrm{~cm}$ to $40 \mathrm{~cm}$ is good for fish culture where the observed transparency level in the present study was within the suitable limit (17 to $29 \mathrm{~cm}$ ). The maximum value of water transparency $29 \mathrm{~cm}$ was recorded at medium size category and the minimum value of transparency $17 \mathrm{~cm}$ was recorded in large size category ponds. Low value of transparency is indicating suitable environment for propagation of green phytoplankton which ultimately enhance the higher production in planktivore tilapia farms (Akter et al. 2015) ${ }^{[1]}$. In addition, pond water level was found to vary from 0.71 to $0.97 \mathrm{~m}$ (Table 1).

During the study period, DO contents of the water varied from $6.20 \mathrm{mg} / \mathrm{l}$ to $7.40 \mathrm{mg} / \mathrm{l}$ (Table 1). However, it could be concluded that dissolved oxygen (DO) concentrations was found to remain in suitable state for tilapia nursing which is similar to the finding of Ali et al. (1982) ${ }^{[3]}$ and Sarker (2000) [23]. On the other hand, $\mathrm{pH}$ is an important water quality parameter in fish farming systems as it affects the toxicity of other compounds to fish such as ammonia and chlorine (Alam and Al-Hafedh 2006) ${ }^{[2]}$. The average $\mathrm{pH}$ values were around 7.0 in each pond throughout the study period which is similar with the findings of Shoko et al. (2014) ${ }^{[24]}$. The present findings suggest that good pond productivity and fish health can be maintained at the current $\mathrm{pH}$ levels. Alkalinity $(\mathrm{mg} / \mathrm{l})$ was found to vary from 50.00 to $64.00 \mathrm{mg} / \mathrm{l}, 46.00$ to 68.00 $\mathrm{mg} / \mathrm{l}$ and 52.00 to $62.00 \mathrm{mg} / \mathrm{l}$ in all size categories ponds respectively which may be comparable with the range 40 to $80 \mathrm{mg} / \mathrm{L}$ of fish ponds (Hossain 2000) ${ }^{[14]}$. Moreover, Mairs (1966) ${ }^{[19]}$ stated that the total alkalinity of $40 \mathrm{mg} / \mathrm{L}$ or more are considered more productive than the water body having lower alkalinity. Regular fertilization might be the cause of higher values of alkalinity in the study ponds. Table 1 is also showing concentration of chlorophyll- $a$ found to vary from 21.59 to $47.83 \mu \mathrm{gl} / 1,19.04$ to $45.93 \mu \mathrm{gl} / \mathrm{l}$ and 13.09 to 47.83 $\mu \mathrm{gl} / 1$ during the study period. The findings are more or less alignment with the findings of Hasan (1998) ${ }^{[12]}$ and Paul (1998) ${ }^{[19]}$. Their findings revealed that values of chlorophylla were ranging from 10 to $200 \mu \mathrm{g} / \mathrm{L}$.

\section{Phytoplankton community}

A total of 61 plankton among 49 genera of phytoplankton belonging to 2 genera of Euglenophyceae, 12 genera of Bacillariophyceae, 9 genera of Cyanophyceae, 26 genera of Chlorophyceae were recorded (Table 2). Among different 
groups of phytoplankton, the most dominant group was Chlorophyceae which comprised of 26 genera and second dominant group was Bacillariophyceae which included 12 genera of phytoplankton. On the other hand, four groups of zooplankton comprised of 12 genera were recorded such as copepoda (2), rotifera (6), cladocera (3) and one crustacean larvae (1).
Fig. 1 is showing the percentages of total phytoplankton and zooplankton. Total phytoplankton covered more that $70 \%$ of the planktonic community. Chlorophyceae comprised more than $44 \%$ in all ponds followed by bacillariophycease, cyanophycease and euglenophyceae (Fig. 2). On the other hand, Rotifera was dominant group among the zooplankton and varied significantly with the size and time.

Table 1: Comparison of physico-chemical parameters (mean) recorded from three sized categories ponds by using ANOVA

\begin{tabular}{|c|c|c|c|c|c|}
\hline Parameters & Small & Medium & Large & F-value & $\begin{array}{c}\text { ANOVA Significance of } \\
\text { Difference }\end{array}$ \\
\hline Water Temperature $\left({ }^{\circ} \mathrm{C}\right)$ & $23.72 \pm 0.71^{\mathrm{b}}(22.79-4.50)$ & $23.84 \pm 0.71^{\mathrm{ab}}(22.91-24.64)$ & $23.99 \pm 0.71^{\mathrm{a}}(23.06-24.79)$ & 5.42 & $*$ \\
\hline Water Level $(\mathrm{m})$ & $0.83 \pm 0.07^{\mathrm{a}}(0.71-0.94)$ & $0.88 \pm 0.06^{\mathrm{b}}(0.75-0.97)$ & $0.83 \pm 0.05^{\mathrm{a}}(0.76-0.91)$ & 3.39 & $*$ \\
\hline Transparency $(\mathrm{cm})$ & $23.17 \pm 2.21(19.00-27.00)$ & $24.00 \pm 2.92(20.00-29.00)$ & $22.92 \pm 2.78(17.00-27.00)$ & 0.51 & NS \\
\hline DO $(\mathrm{mg} / \mathrm{L})$ & $6.69 \pm 0.33(6.20-7.20)$ & $6.85 \pm 0.29(6.40-7.30)$ & $6.79 \pm 0.35(6.30-7.40)$ & 0.69 & NS \\
\hline Water $\mathrm{pH}$ & $7.38 \pm 0.15(7.15-7.56)$ & $7.41 \pm 0.19(7.10-7.62)$ & $7.45 \pm 0.16(7.20-7.65)$ & 0.61 & NS \\
\hline Alkalinity $(\mathrm{mg} / \mathrm{L})$ & $58.50 \pm 4.83(50-64)$ & $56.67 \pm 6.46(46-68)$ & $56.50 \pm 3.32(52-62)$ & 0.86 & NS \\
\hline Chlorophyll $-a(\mu \mathrm{g} / \mathrm{L})$ & $33.68 \pm 7.48(21.59-47.83)$ & $31.54 \pm 8.12(19.04-45.93)$ & $32.83 \pm 11.22(13.09-47.83)$ & 0.19 & NS \\
\hline
\end{tabular}

$\mathrm{NS}=$ Values are not significantly different $(P>0.05)$

* Values with different superscript letters in the same row indicate a significant difference at $5 \%$ significance level based on one-way ANOVA followed by Tukey's test.

Table 2: Generic status of different groups of plankton identified from nursery ponds

\begin{tabular}{|c|c|c|}
\hline Phytoplankton & Phytoplankton & Zooplankton \\
\hline Euglenophyceae & Chlorophyceae & Copepoda \\
\hline Euglena & Ankistrodesmus & Cyclops \\
\hline Phacus & Botryococcus & Diaptomus \\
\hline Cyanophyceae & Chlorella & Rotifera \\
\hline Anabaena & Chlorogonium & Asplanchna \\
\hline Aphanocapsa & Cladophora & Brachionus \\
\hline Chroococcus & Closterium & Filinia \\
\hline Microcystis & Coelastrum & Lecane \\
\hline Nostoc & Cosmarium & Keratella \\
\hline Oscillatoria & Crucigenia & Monostyla \\
\hline Synecococcus & Gonatozygon & Cladocera \\
\hline Goleocapsa & Micractinium & Daphnia \\
\hline Merismopedia & Microspora & Diaphanosoma \\
\hline Bacillariophyceae & Monoraphidium & Moina \\
\hline Amphipleura & Oedogonium & Crustacean Larvae \\
\hline Astorionella & Pediastrum & \multirow{12}{*}{ Nauplius } \\
\hline Cyclotella & Scenedesmus & \\
\hline Diatoma & Sphaerocystis & \\
\hline Fragillaria & Spirogyra & \\
\hline Melosira & Staurastrum & \\
\hline Navicula & Stigeoclonium & \\
\hline Nitzschia & Tetraedron & \\
\hline Pinnularia & Ulothrix & \\
\hline Surirella & Volvox & \\
\hline Synedra & Zygnema & \\
\hline \multirow[t]{2}{*}{ Tabellaria } & Oocystis & \\
\hline & Tetraspora & \\
\hline
\end{tabular}

Table 3: Mean $( \pm \mathrm{SD})$ value and ranges of planktonic community $\left(\times 10^{3}\right.$ cells/L) value in the sampling nursery ponds during the sampling period.

\begin{tabular}{|c|c|c|c|c|c|}
\hline \multirow{2}{*}{ Groups } & \multicolumn{3}{|c|}{ Sampling ponds } & \multirow[t]{2}{*}{ F -value } & \multirow{2}{*}{ ANOVA Significance of Difference } \\
\hline & Small & Medium & Large & & \\
\hline Euglenophyceae & $0.97 \pm 0.53(00-1.80)$ & $1.00 \pm 0.52(00-1.86)$ & $0.99 \pm 0.57(00-1.65)$ & 0.01 & NS \\
\hline Cyanophyceae & $3.97 \pm 0.56(3.30-5.12$ & $3.74 \pm 0.93(1.74-4.96)$ & $3.8 \pm 0.65(2.56-4.65)$ & 0.32 & NS \\
\hline Bacillariophyceae & $5.32 \pm 0.95(4.34-7.36)$ & $5.42 \pm 0.94(4.20-7.26)$ & $5.52 \pm 0.68(4.64-6.60)$ & 0.16 & NS \\
\hline Chlorophyceae & $8.22 \pm 0.95(7.20-9.92)$ & $8.45 \pm 0.75(6.96-9.57)$ & $8.52 \pm 1.16(6.72-9.92)$ & 0.29 & NS \\
\hline Copepoda & $1.72 \pm 0.52(0.96-2.70)$ & $1.72 \pm 0.74(00-2.61)$ & $1.71 \pm 0.60(0.87-2.79)$ & 0.002 & NS \\
\hline Rotifera & $3.43 \pm 0.63^{\mathrm{a}}(2.48-4.48)$ & $3.39 \pm 0.80^{\mathrm{b}}(2.10-4.65)$ & $3.06 \pm 0.77^{\mathrm{c}}(1.9-4.35)$ & 3.08 & $*$ \\
\hline Cladocera & $1.22 \pm 0.51(00-1.92)$ & $1.24 \pm 0.62(00-2.31)$ & $1.13 \pm 0.62(00-1.65)$ & 0.13 & NS \\
\hline Crustacean Larvae & $0.91 \pm 0.51(0.00-1.55)$ & $0.68 \pm 0.46(0.00-1.45)$ & $0.91 \pm 0.49(0.00-1.60)$ & 0.95 & NS \\
\hline
\end{tabular}

$\mathrm{NS}=$ Values are not significantly different $(P>0.05)$

* Values with different superscript letters in the same row indicate a significant difference at $5 \%$ significance level based on one-way ANOVA followed by Tukey's test. 


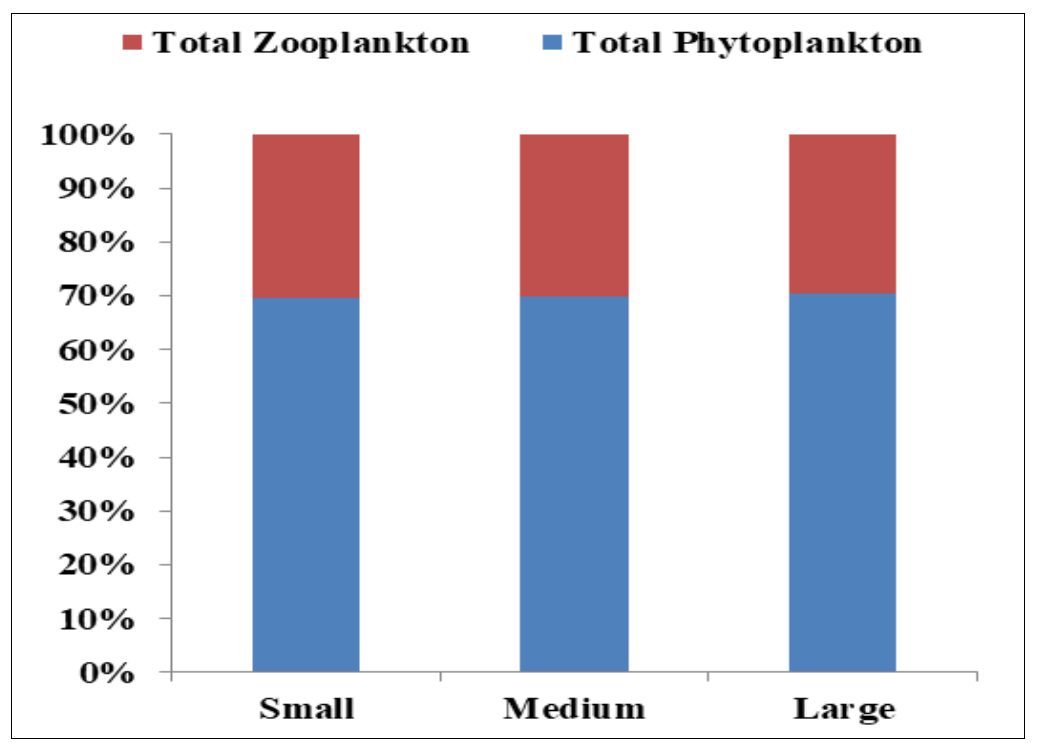

Fig 1: Percentages of total phytoplankton and total zooplankton in all size categorized pond during the sampling period
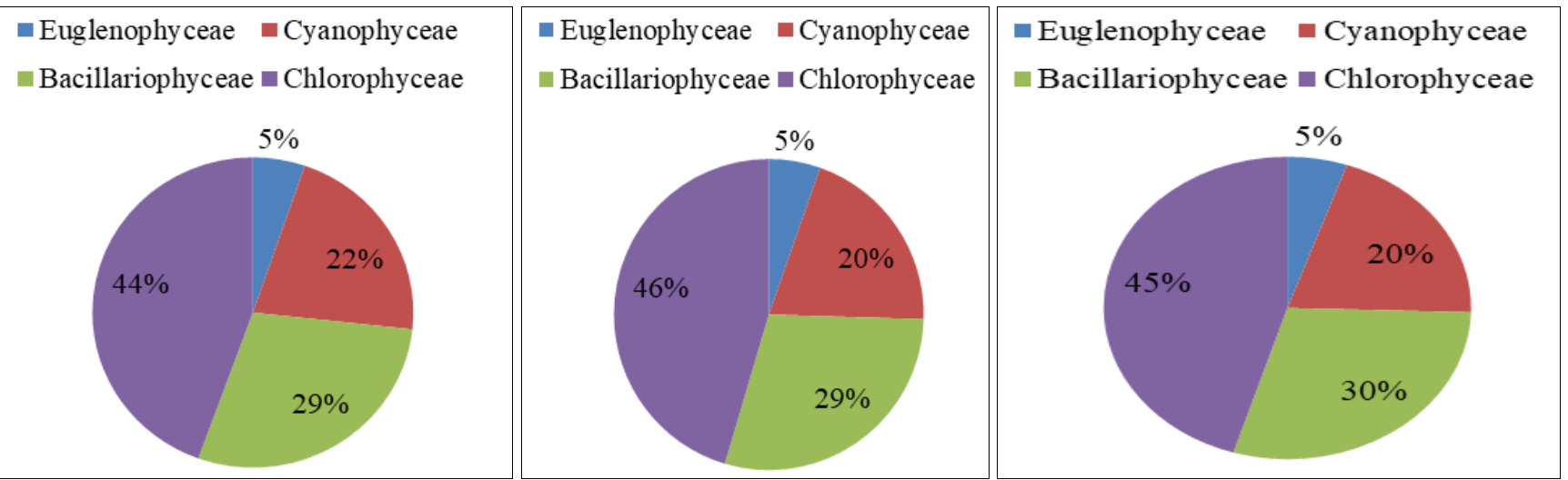

Fig 2: Percentages of different phytoplankton communities during the study period (a, b c, are indicating the size category as small, medium and large)

\section{Conclusion}

Through analyzing different water quality parameters, it can be concluded that the physico-chemical water quality parameters and planktonic abundance in nursery pond found within optimum ranges. All data from the findings will help the farmer to uplift their knowledge about maintaining the proper water quality as well as to maximize the fish growth and profit. This can ultimately promote sustainable livelihoods in major areas of economic life in the small-scale tilapia farming of the northwest part of Bangladesh.

\section{References}

1. Akter S, Rahman MM, Akter M. Composition and abundance of phytoplankton population in fish ponds of Noakhali District, Bangladesh. American-Eurasian Journal of Agricultural \& Environmental Sciences 2015;15(11):2143-2148.

2. Alam A, Al-Hafedh YS. Diurnal dynamics of water quality parameters in an aquaculture system based on recirculating green water technology. Journal of Applied Science and Environmental Management 2006;10:19-21.

3. Ali MH, Akber MA and Rahman MH. Utilization of fish ponds in Mymensingh district. Bangladesh Journal of Agricultural Research 1982;5:1-2:103-104.

4. Barber HG, Haworth EY. A guide to Morphology of the Diatom frustules. Freshwater Biological Association 1981,122 .
5. Bellinger EG. A key to the common Algae. The institution of water and Environmental management $1992,138$.

6. Boyd CE. Water quality management of pond fish culture. Elsvier Science Publishing Company Amsterdam- Oxford, New York 1982,318.

7. Boyd CE, Tucker CS. Water quality and pond soil analysis for aquaculture. Alabama Agriculture Experiment Station, Alabama, USA 1992,183.

8. Gupta N, Haque MM, Khan M. Growth performance of tilapia fingerling in cage in ponds managed by Adivasi households: An assessment through length weight relationship. Journal of Bangladesh Agricultural University 2012;10(1):149-155.

9. Department of Fisheries. National Fish Week (02-08 July). Compendium. Department of Fisheries, Ministry of Fisheries and Livestock, Government of the Peoples' Republic of Bangladesh 2014,124.

10. FAO. Fishery statistics: capture production. Food and Agriculture Organisation of the United Nations, Rome 2015;84:703.

11. Fessehaye Y. Natural mating in Nile tilapia (Oreochromis niloticus L.) Implications for reproductive success, inbreeding and cannibalism. Wageningen: Wageningen UR 2006,150.

12. FRSS. Yearbook of Fisheries Statistics of Bangladesh. Fisheries Resources Survey System (FRSS) 2017. 
13. Hasan MA. Development of carp polyculture techniques with small indigenous fish species mola (Amblypharyngodon mola), chela (Chela cachius) and punti (Puntius sophore). M.S. dissertation, Department of Fisheries Management, Bangladesh Agricultural University, Mymensingh 1998, 71.

14. Hossain MY. Effects of is phosphorus organic and inorganic fertilizers on water quality parameters in fish ponds and biological production. MS Thesis, Department of Fisheries Management, BAU, Mymensingh 2000, 24.

15. Jhingran VG. Fish and Fisheries India. 3rd edition. Hindustan Publishing Corporation, India 1991.

16. Johnson B. Developing a successful aquaculture enterprise in the North Central Region, Combined North Central and Ninth Annual Minnesota Aquaculture Conference and Tradeshow, Radisson South 1995, 1-9.

17. Kunlasak K, Chitmanat C, Whangchai N, Promya J, Lebel L. Relationships of Dissolved Oxygen with Chlorophyll-a and Phytoplankton Composition in Tilapia Ponds in northern Thailand. International Journal of Geosciences 2013;4:46-53.

18. Lind ME, Brook AJ. A key to the common desmids of the Engkishlake District. Freshwater Biological Association Scientific Publication 1980, 122.

19. Mairs DF. A total alkalinity atlas for marine lake waters. Limnology and Oceanography 1966;11:68-72.

20. Paul S. Comparison between carp polyculture system with silver carp, Hypopthalmichthys molitrix. MS dissertation, Department of Fisheries Management, Bangladesh Agricultural University, Mymensingh. pp. 85.Pontin MR. 1978. A key to the freshwater planktonic and semi-planktonic rotifera of the british Isles. Freshwater Biological Association Scientific Publication 1998, 197.

21. Pontin MR. A key to the freshwater planktonic and semiplanktonic rotifera of thebritish Isles. Freshwater Biological Association Scientific Publication 1978,197.

22. Rahman MS. Water quality management: Aquaculture. BRAC Prokashana, Mohakhali, Dhaka, Bangladesh 1992, 84.

23. Sarker MN. Effects of periphyton on monoculture of GIFT tilapia. MS thesis, Department of Fisheries Management, Bangladesh Agricultural University, Mymensingh 2000, 88.

24. Shoko AP, Limbu SM, Mrosso HDJ, Mgaya YD. A comparison of diurnal dynamics of water quality parameters in Nile tilapia (Oreochromis niloticus, Linnaeus, 1758) monoculture and polyculture with African sharp tooth catfish (Clarias gariepinus, Burchell, 1822) in earthen ponds, Tanzania. International Aquatic Research 2014;6:56. 